\title{
Sprawozdanie ze stanu realizacji inwestycji budowy nowej siedziby Archiwum Narodowego w Krakowie za 2018 r.
}

Nowa siedziba Archiwum Narodowego w Krakowie budowana jest na działce nr 219/15 obręb 8 Śródmieście, przylegającej do Cmentarza Rakowickiego w Krakowie od jego południowej strony. Nieruchomość została przekazana Archiwum przez Agencję Mienia Wojskowego w 2013 r. W 2018 r. nowo powstającemu budynkowi został nadany adres: ul. Rakowicka 22E. Nowy obiekt widoczny jest z Dworca Głównego PKP, z którego dotarcie pieszo do Archiwum zajmie nie więcej niż pięć minut.

Przygotowanie do inwestycji rozpoczęło się w 2013 r. wraz ze sporządzeniem programu funkcjonalno-użytkowego nowej siedziby. W 2014 r. rozpisano konkurs na opracowanie koncepcji architektoniczno-użytkowej budynku. W 2015 r. podpisano umowę na wykonanie dokumentacji projektowej. W 2016 r. uzyskano niezbędne decyzje administracyjne o pozwoleniu na budowę oraz rozpisano przetargi na obsługę prawną i inwestycyjną oraz na realizację inwestycji. Same roboty budowlane rozpoczęły się w kwietniu $2017 \mathrm{r}$. Zgodnie z aktualnym harmonogramem terminem oddania budynku do użytkowania jest maj 2020 r. Następnie zacznie się etap montażu pierwszego wyposażenia budynku. W lipcu 2020 r. rozpocznie się przeprowadzka z sześciu zajmowanych dotychczas lokalizacji. W drugim kwartale 2021 r. Archiwum będzie mogło prowadzić działalność już tylko w nowym budynku, opuszczając wszystkie dotychczasowe siedziby w Krakowie i w Spytkowicach koło Zatoru.

Budynek przy ul. Rakowickiej 22E pomieści ok. 70000 mb materiałów archiwalnych. Posiada osiem kondygnacji (w tym jedną podziemną) w segmencie magazynowym i sześć w biurowym (także z jedną podziemną). W 2018 r. przygotowano dokładny projekt wykonania i rozmieszczenia regałów w magazynach, uwzględniając wszystkie formaty przechowywanej dokumentacji oraz funkcje poszczególnych magazynów. W tym samym roku Archiwum zleciło również stworzenie bazy danych umożliwiającej dokładne zaplanowanie rozłożenia wszystkich jednostek archiwalnych na poszczególnych regałach z dokładnością do pojedynczej półki. Dzięki tym dwóm projektom możliwa będzie sprawna przeprowadzka i precyzyjne rozmieszczenie zasobu w nowej siedzibie, niezależnie od kolejności przewożenia akt. Stworzono także podwaliny pod przyszły kompletny inwentarz topograficzny zasobu w nowych magazynach.

Postęp robót budowlanych można śledzić w galerii fotografii na stronie internetowej Archiwum. Na początku 2018 r. odebrano budynek w stanie „,zero”, tj. ze wszystkimi elementami konstrukcji do poziomu gruntu. Następnie zaczęto wznosić kolejne kondygnacje aż do poziomu dachu. W czerwcu 2018 r. ukończony był stan surowy otwarty całego budynku. W tym miesiącu odbyła się również uroczystość wmurowania kamienia węgielnego. Na akcie erekcyjnym nowej siedziby Archiwum w dniu 8 czerwca złożyli podpisy: Wiceminister Kultury i Dziedzictwa Narodowego - Magdalena Gawin, Naczelny Dyrektor 
Archiwów Państwowych - Wojciech Woźniak, Prezydent Miasta Krakowa - Jacek Majchrowski, członek zarządu Województwa Małopolskiego - Grzegorz Lipiec, przedstawiciel Generalnego Wykonawcy wiceprezes wykonawczy Skanska S.A. - Richard Burleigh, gospodarz spotkania dyrektor Archiwum Narodowego - Wojciech Krawczuk oraz ks. Kardynał Stanisław Dziwisz, który poświęcił dokument i kamień węgielny. W uroczystości, która stała się podsumowaniem pierwszej połowy prac budowlanych, wzięli udział licznie przybyli przedstawiciele archiwów państwowych, władz samorządowych, instytucji kultury, środowisk naukowych oraz mediów. Dla gości przewidziano dodatkowe atrakcje, m.in. wystawę ukazującą historię i bogate zbiory naszej instytucji, możliwość zwiedzenia dostępnych części powstającego gmachu oraz poczęstunek.

Do końca 2018 r. wstawiono wszystkie okna oraz wykonano szklaną ścianę nad głównym wejściem do gmachu. Przy segmencie biurowym wzniesiono konstrukcję podtrzymującą „drugą skórę” budynku, czyli szklaną fasadę zawierającą ruchome elementy (żaluzje), tworzącą system dodatkowej izolacji i wymiany powietrza dla segmentu. Cały segment obłożono izolacją z wełny mineralnej oraz rozpoczęto montaż „,pierwszej skóry”, czyli okładziny z płyt z betonu architektonicznego z włóknami szklanymi (GRC). Prace przy elewacji segmentu biurowego zakończą się w połowie 2019 r. i dopiero wtedy rozpocznie się też montaż elewacji z płyt z betonu GRC na segmencie magazynowym (jedyna elewacja w tej części obiektu). Pod względem estetycznym szklana elewacja na znajdującym się bliżej cmentarza segmencie biurowym ma za zadanie odbijać zieleń cmentarza i „ukrywać” ogrom budowli przed widzem patrzącym od tamtej strony. Okładzina segmentu magazynowego - wyższego, pozbawionego okien prostopadłościanu, położonego od strony Dworca Głównego PKP - ma ozdobić budynek i ,rozwibrować” światło padające od południowej strony na cały gmach.

Równolegle $\mathrm{z}$ pracami prowadzonymi przy zewnętrznych ścianach rozpoczęto $\mathrm{w}$ środku budynku montaż wentylacji, instalacji wodno-kanalizacyjnych, elektrycznych, teletechnicznych i przeciwpożarowych. Trwa także wykonanie central każdego rodzaju instalacji w pomieszczeniach technicznych w podziemnej kondygnacji. System ppoż. w magazynach archiwalnych działa na zasadzie „suchych rur” napełniających się dopiero w trakcie akcji gaśniczej oraz „mgły wodnej”, czyli punktowego gaszenia pod wielkim ciśnieniem minimalną ilością wody, tak aby ograniczyć do minimum szkody wywołane przez samo gaszenie źródła ognia. W nowej siedzibie zaplanowany jest nowoczesny BMS (building management system), czyli łączne zarządzanie wszystkimi systemami automatycznego sterowania w budynku, dzięki którym może on być traktowany jako „budynek inteligentny”.

Do końca 2018 r. ukończono także wszystkie ścianki działowe wewnątrz obiektu oraz przystąpiono do wykańczania ścian, sufitów i posadzek. Na parkingu przy budynku ukończono wiercenie 25 sond głębinowych, które będą podstawowym źródłem ciepła i chłodzenia dla całego budynku. Zakończyła się także odbudowa dwóch małych budowli będących pozostałościami dawnej Twierdzy Kraków. Przeznaczeniem jednej będzie stacja transformatorowa oraz miejsce na zapasowy agregat prądotwórczy. W drugiej ma być urządzony śmietnik.

W połowie roku przygotowano i skierowano do realizacji kompleksowe zmiany w projekcie wykonawczym budynku wynikające z drobnych korekt przeznaczenia niektórych pomieszczeń oraz z potrzeby montażu dodatkowej instalacji teletechnicznej, wentylacji 
oraz precyzyjnej klimatyzacji dedykowanych Zapasowemu Repozytorium Cyfrowemu Archiwów Państwowych, które ma powstać na IV piętrze segmentu biurowego. Dzięki umowie z Narodowym Archiwum Cyfrowym z 2017 r. użytkownikiem i administratorem repozytorium będzie ta właśnie instytucja, która tym samym otworzy swój oddział w Krakowie przy siedzibie Archiwum Narodowego w Krakowie.

Budowa przebiega zgodnie $\mathrm{z}$ harmonogramem i zmierza bez przeszkód do zaplanowanego końca.

Pawet Ząbczýnski, Lilianna Pochwalska Archiwum Narodowe w Krakowie 